\title{
Peranan Biaya Kualitas dalam Mendukung Pengendalian Kualitas Produk pada UD. Mutiara Rasa Jember
}

\section{Isnay Jannatur Rizka ${ }^{1 *}$}

Prodi Akuntansi, Fakultas Ekonomi, Universitas Muhammadiyah , Jember, Indonesia

\section{A R T I C L E I N F O}

Article history:

Received 19 December 2018

Received in revised form 30 December 2018

Accepted 01 January 2019

Available online 18

February 2019

Kata Kunci:

Kualitas, Peranan Biaya Kualitas, Pengendalian

Kualitas Produksi

Keywords:

Quality, Role of Quality Costs, Production Quality Control

\begin{abstract}
A B S T R A K
Penelitian mengenai Peranan Biaya Kualitas Dalam Mendukung Pengendalian Kualitas Produk Pada UD. Mutiara Rasa Jember merupakan studi kasus pada perusahaan. Tujuan yang ingin dicapai yaitu untuk mengetahui Laporan Biaya Kualitas dalam mendukung Pengendalian Kualitas Produk pada UD. Mutiara Rasa Jember. Metode penelitian laporan data yang digunakan dengan cara mengidentifikasi biaya-biaya untuk menyusun laporan biaya kualitas. Dari hasil laporan biaya kualitas yang diperoleh informasi bahwa biaya kualitas total besarnya berbeda dan cenderung menurun terhadap presentase penjualan. Hasil penelitian menunjukan bahwa usaha peningkatan kualitas, dari pada melakukan kesalahan atau pengerjaan ulang lebih baik melakukan tindakan-tindakan pencegahan untuk mdenghindari kualitas rendah. Sehingga perusahaan dapat meningkatkan atau mempertahankan kepuasan konsumen.
\end{abstract}

\section{A B S T R A C T}

The research about the Role of Costs Quality in Supporting Product Quality Control at UD. Mutiara Rasa Jemberis a case of study in the enterprise. The purpose to be achieve is to find out the report of Costs Quality in supporting Produsct Quality Control at UD. Mutiara Rasa Jember. The method of data report is to identifying cost to make the costs quality report. The researcher get information from the result of costs quality if the total costs of quality is diferrent and occur of the percentage of sales. The research indicated that the effort of quality improvement, than make a mistakes or reworking it is better to take preventive measure to avoid low quality. So, the enterprise can increase or maintain the customers satisfaction.

\footnotetext{
* Corresponding author.

E-mail addresses: adinay2507@gmail.com (Isnay Jannatur Rizka)
} 


\section{Pendahuluan}

Di era globalisasi saat ini, menimbulkan persaingan yang ketat antar pelaku ekonomi. Baik dalam negeri maupun luar negeri. Perusahaan dituntut untuk semakin kreatif menciptakan produk-produk yang tidak hanya mampu bersaing dengan sesama produk dalam negeri, namun juga harus mampu bersaing dengan produk-produk dari negara lain. Dan ternyata perusahaan diharuskan mampu memberikan hasil produksi yang berkualitas. Tanpa adanya kualitas produk yang baik, sudah pasti produk mereka tidak akan bisa laku dipasaran. Tentu saja hal tersebut tidaklah mudah untuk bisa dicapai oleh perusahaan. Sedangkan untuk menghasilkan produk-produk yang berkualitas, perusahaan harus mampu menganilisis biaya kualitas. Yang mana biaya kualitas itu sendiri terdiri dari biaya pencegahan, biaya penilaian, biaya kegagalan internal, dan biaya kegagalan eksternal (Hansen dan Mowen 2007:670-671).

Pengertian biaya menurut Dunia dan Abdullah (2012:22) Biaya adalah pengeluaran-pengeluaran atau nilai pengorbanan untuk memperoleh brang atau jasa yang berguna untuk masa yang akan datang, atau mempunyai manfaat melebihi satu peiode akuntansi. Menurut Yamit (2010:8) membuat definisi kualitas yang lebih luas cakupannya, yaitu kualitas merupakan suatu kondisi dinamis yang berhubungan dengan produk, jasa, manusia, proses, dan lingkungan yang memenuhi atau melebihi harapan. Menurut Hansen dan Mowen (2004:443) mengatakan bahwa Biaya Kualitas adalah biaya yang timbul karena mungkin ataun telah terdapat produk yang buruk kualitasnya. Menurut Dewi dan Kristanto (2015:105), biaya kualitas tidak untuk memperoleh kualitas (kualitas) tapi juga merupakan biaya-biaya yang timbul untuk mencegah terjadinya kualitas yang rendah. Jenis Biaya kualitas dapat dikelompokkan ke dalam 3 penggolongan besar: (1) Biaya pencegahan, (prevention cost) Biaya yang terjadi untuk mencegah terjadinya kegagalan produk atau produksi produk-produk yang tidak sesuai denga spesifikasi yang ditetapkan. Biaya pencegahan adalah biaya yang di kerluarkan untuk mendesai produk dan sistem produksi berkualitas tinggi, termasuk biaya untuk menerapkan dan memelihara sistem tersebut, (2) Biaya penilaian (appraisal cost), Biaya penilaian adalah biaya yang terjadi untuk menentukan apakah produk yang dihasilkan sesuai dengan spesifikasi yang ditetapkan, (3) Biaya Kegagalan (failure cost), Biaya kegagalan terbagi menjadi dua yaitu: (a) Biaya Kegagalan Internal (internal failure cost), Kegagalan internal adalah biaya yang terjadi ketika produk yang tidak sesuai dengan spesifikasi dapat dideteksi sebelum dikirim ke konsumen (selama proses produksi), (b) Biaya kegagalan eksternal (external failure cost) Biaya kegagalan eksternal terjadi karena produk-produk yang tidak sesuai dengan spesifikasi dideteksi setelah dikirim kepelanggan.

Menurut Rudy Prihantoro (2012:6) Pengendalian mutu atau kualitas adalah suatu sistem kendali yang efektif untuk mengoordinasikan usaha-usaha penjagaan kualitas, dan perbaikan mutu dari kelompok-kelompok dalam organisasi produksi, sehingga diperoleh suatu produksi yang sangat ekonomis serta dapat memuaskan kebutuhan dan keinginan konsumen. Menururt Hansen dan Mowen (2004:443) biaya kualitas adalah biaya-biaya yang timbul karena mungkin atau telah terdapat produk dengan kualitas yang buruk. Definisi ini mengimplikasikan bahwa berhubungan dengan dua subkategori dari kegiatankegiatan yang terkait dengan kualitas yakni kegiatan pengendalian dan kegiatan karena kegagalan. Menurut Hansen dan Mowen (2005:5), kualitas adalah ukuran relatif dari kebaikan (goodness). UD. Mutiara Rasa yang berdomisili di Jember adalah perusahaan yang bergerak di bidang industri makanan khas kota Jember yaitu suwar-suwir.

Penelitian ini dikuatkan oleh penelitian sebelumnya yang dilakukan oleh : Lilis Puji (2017) yang menyatakan Hasil penelitian yang telah dilakukan pada UD. Batu Licin menunjukkan bahwa secara secara parsial biaya pencegahan dan biaya penilaian berpengaruh signifikan terhadap produk rusak dengan sig. 0,048 dan 0,044 . Secara simultan biaya pencegahan dan biaya penilaian berpengaruh signifikan terhadap produk rusak dengan nilai sig. 0,049 pada tingkat sig. 0.05. hal senada juga diungkapkan Eliyana R. N. (2009) disimpulkan bahwa biaya kualitas merupakan modal yang berharga dalam rangka meminimalkan produk rusak yan terjadi pada CV. Aneka Ilmu Semarang. Adanya hubungan yang signifikan antara biaya kualitas dengan produk rusak perlu diperhatikan bagi manajemen perusahaan dalam pencapaian kualitas produk yang lebih baik secara menyeluruh sehingga dapat meminimalisir produk rusak yang terjadi. Meirlina Tanjung (2016) juga menyatakan Hasil analisis menunjukkan bahwa biaya pencegahan, biaya penilaian, biaya kegagalan internal mengalami fluktuasi tiap tahunnya, tetapi pada biaya kegagalan eksternal mengalami kenaikan tiap tahunnya dan penurunan pangsa pasar yang diakibatkan oleh kehilangan penjualan, sehingga mempengaruhi kinerja perusahaan. Riki Martusa (2011) menyatakan berdasarkan hasil analisis data bahwa PT. Perkebunan Nusantara VIII dapat mengetahui jenis dan proporsi biaya kualitas yang terjadi dalam kegiatan pengendalian kualitasnya, sehingga perusahaan dapat menentukan tindakan yang harus dilakukan untuk mencapai biaya kualitas yang lebih efisien.

UD. Mutiara rasa merupakan perusahaan yang mana proses produksinya mengubah bahan baku menjadi barang jadi. Bahan baku di UD. Mutiara Rasa yang masih rendah karena di Indonesia memiliki 
pergantian musim panas ke musim hujan. Pada saat musim panas kualitas singkong tidak akan baik dan pada saat musim hujan kualitas singkong yang dihasilkan juga tidak baik maka UD. Mutiara Rasa akan mengolah singkong menjadi tape sebaik mungkin agar menghasilkan suwar suwir yang kualitasnya baik. UD. Mutiara Rasa dalam proses produksinya akan mengeluarkan biaya produksi. Jika kualitas bahan baku tidak bagus maka akan mengeluarkan biaya produksi yang cukup tinggi dan jika kualitas bahan baku tidak baik kemungkinan akan mengakibatkan produk suwar suwir menjadi cacat atau rusak.

Berdasarkan latar belakang masalah yang telah penulis uraikan diatas, maka penulis merumuskan masalah: Bagaimana peranan biaya kualitas dalam mendukung pengendalian kualitas produk pada UD. Mutiara Rasa khas Oleh-oleh Jember ditinjau dari (1) Biaya Pencegahan, (2) Biaya Penilaian, (3) Biaya Kegagalan Internal dan (4) Biaya Kegagalan Eksternal.

Sesuai dengan permasalahan penelitian yang telah dirumuskan sebelumnya, penelitian ini mempunyai tujuan sebagai berikut: Untuk mengetahui bagaimana peranan biaya kualitas dalam mendukung pengendalian kualitas produk pada UD. Mutiara Rasa khas Oleh-oleh Jember ditinaju dari (1) Biaya Pencegahan, (2) Biaya Penilaian, (3) Biaya Kegagalan Internal dan (4) Biaya Kegagalan Eksternal

\section{Metode}

Dalam memperoleh data sebagai bahan penelitian ini maka peneliti menggunakan metode deskriptif kualitatif. Jenis data yang dikumpulkan oleh peneliti menggunakan Data Primer dan Data Sekunder. Teknik pengumpulan data menggunakan Wawancara dan Dokumentasi.

Teknik Analisis Data

(1) Mengidentifikasi biaya-biaya yang terjadi kedalam biaya kualitas, (2) Mengklasifikasikan atau mengelompokkan biaya kualitas kedalam: (a) Biaya Pencegahan, (b) Biaya Penilaian, (c) Biaya Kegagalan Internal, d. Biaya Kegagalan Eksternal, (3) Menyusun laporan biaya kualitas, (4) Membandingkan laporan biaya kualitas dengan anggaran biaya kualitas, (5) Menyimpulkan hasil laporan hasil dan laporan anggaran biaya kualitas.

\section{Hasil dan pembahasan}

Berdasarkan hasil wawancara dan data yang ada pada UD. Mutiara Rasa Jember, maka dapat diidentifikasi biaya-biaya yang termasuk kedalam biaya kualitas, yaitu sebagai berikut:

\section{Biaya Pencegahan}

Biaya Pencegahan yaitu biaya yang dikeluarkan untuk mencegah terjadinya produk yang cacat atau tidak sesuai dengan spesifikasi yang ditetapkan. Biaya pencegahan ini terdiri dari: a. Biaya Program Pelatihan Kualitas, dan b. Biaya Pemilihan dan Mengevaluasi Bahan Baku.

\section{Biaya Penilaian}

Biaya Penilaian yaitu biaya yang terjadi untuk menentukan apakah produk yang dihasilkan sesuai dengan spesifikasi yang ditetapkan. Biaya penilaian terdiri dari: a. Biaya Pemeriksaan atau Pengujian Bahan Baku, b. Biaya Pemeriksaan Kemasan, dan c. Biaya Pengawasan Kegiatan Produksi.

\section{Biaya Kegagalan Internal}

Biaya Kegagalan Internal yaitu biaya yang terjadi ketika produk tidak sesuai spesifikasi dapat dideteksi sebelum dikirimkan ke konsumen. Biaya kegagalan internal terdiri dari: a. Biaya Pemeriksaan Ulang, b. Biaya Pengerjaan Ulang.

\section{Biaya Kegagalan Eksternal}

Biaya Kegagalan Eksternal yaitu biaya yang terjadi karena produk yang tidak sesuai spesifikasi dideteksi setelah dikirimkan ke konsumen. Biaya kegagalan eksternal terdiri dari: a. Biaya Keluhan Konsumen, b. Biaya Garansi. 
Tabel 1. Laporan Biaya Kualitas

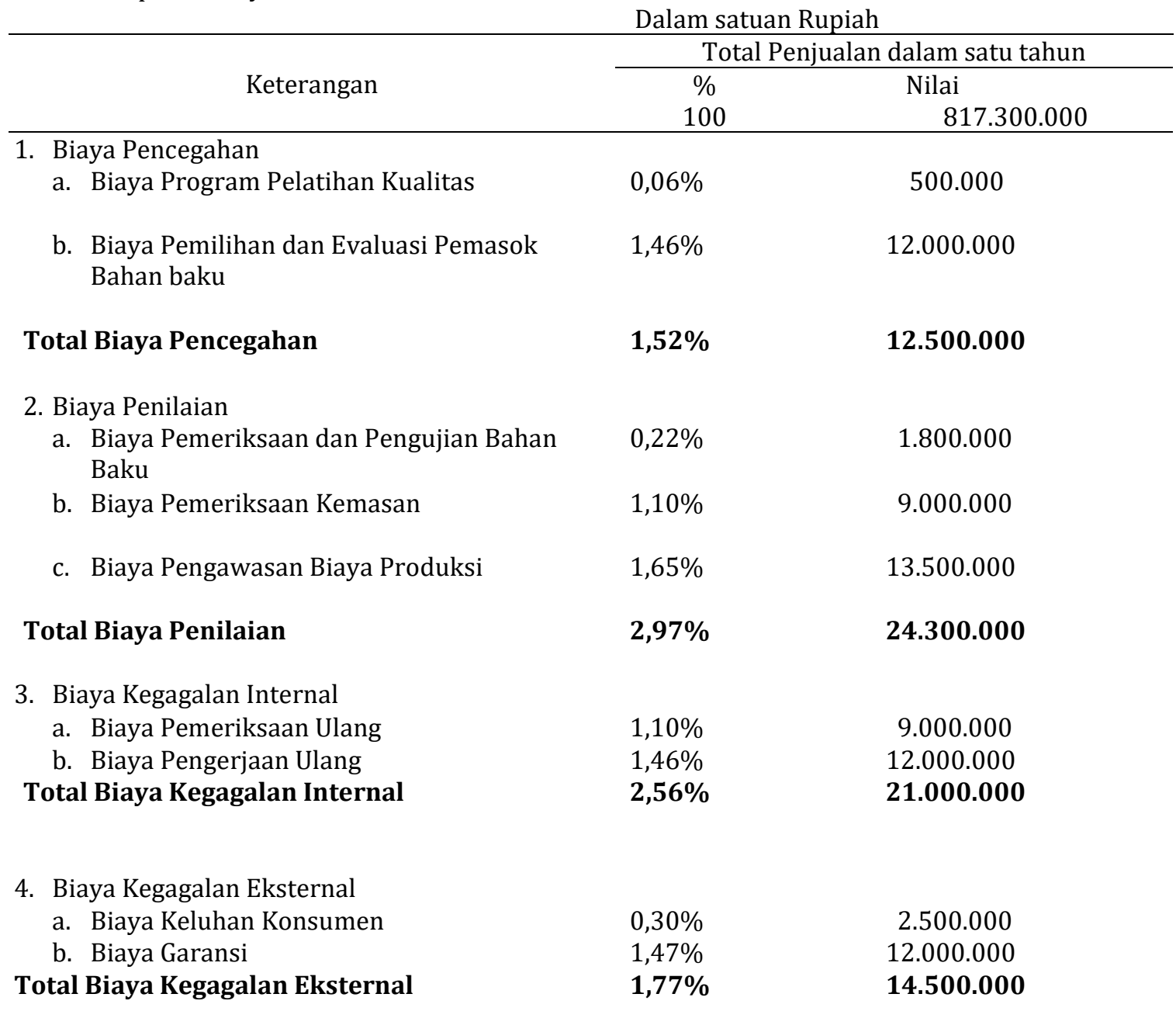

Sumber: UD. Mutiara Rasa Jember 2017 (diolah peneliti)

\section{Peranan Biaya Kualitas Dalam Mendukung Pengendalian Kualitas Produk}

Pengendalian biaya kualitas yang dilakukan dengan memanfaatkan anggaran biaya kualitas dengan memperhitungkan jumlah hasil yang didapat dari biaya tersebut. Dalam penyusunan anggaran biaya kualitas UD. Mutiara Rasa Jember menentukan besarnya yang ditetapkan di setiap biaya-biaya yang dikeluarkan sehingga UD. Mutiara Rasa Jember diharapkan dapat mengendalikan biaya yang sudah direalisasikan. Dan karena itu UD. Mutiara Rasa Jember menggunakan anggaran biaya kualitas sebagai salah satu alat yang mempunyai peran penting yaitu sebagai alat untuk mendukung pengendalian kualitas produk. Dari keempat jenis biaya kualitas yaitu, biaya pencegahan, biaya penilaian, biaya kegagalan internal dan biaya kegagalan eksternal dari bulan januari sampai dengan bulan desember tahun 2017 masing-masing jumlahnya berbeda. Dari hasil pengklasifikasian biaya kualitas diperoleh informasi bahwa biaya kualitas jumlah setiap bulannya berubah-ubah terhadap presentase dari penjualan. Jumlah besarnya biaya kualitas setiap bulan mengalami kenaikan dan perununan di bulan tertentu.

Dapat dilihat dari rekapitulasi di empat jenis biaya kualitas, yaitu sebagai berikut:

1. Biaya Pencegahan

Biaya pencegahan yang dikeluarkan oleh UD. Mutiara Rasa Jember dalam total penjualan satu tahun yaitu 1,52\%. Biaya yang dikeluarkan sebesar Rp. 12.500.000, jadi dapat dikatakan bahwa Biaya pencegahan mendukung dalam pengendalian kualitas produk. Naik turunnya biaya pencegahan berpengaruh pada terjadinya peningkatan kualitas produk. penurunan.

\section{Biaya Penilian}

Biaya penilaian yang dikeluarkan oleh UD. Mutiara Rasa Jember yaitu 2,97\% dan biaya yang dikeluarkan sebesar Rp. 24.300.000. Serta biaya penilaian sangat efektif dalam mendukung pengendalian 
produk pada UD. Mutiara Rasa Jember. Karena selama tahun 2017 UD. Mutiara Rasa Jember tidak mengalami kenaikan dalam pengeluarannya.

\section{Biaya Kegagalan Internal}

Biaya kegagalan internal juga stabil pada UD. Mutiara Rasa Jember karena selama pengeluarannya tidak mengalami kenaikan yang pengeluarannya 2,56\% dan sebesar Rp. 21.000.000 . Karena UD. Mutiara Rasa Jember dalam proses produksinya tidak terlalu banyak masalah akan tetapi setiap bulannya mengeluarkan biaya yang sama pada biaya kegagalan internal. Biaya pemeriksaan ulang dapat dinilai dari pengembalian produk terbanyak dikemasan tas berat $1 \mathrm{~kg}$ yaitu sebesar 250 kemasan yang presentasenya adalah 2,03\%. Biaya pengerjaan ulang dapat dinilai dari seberapa besar produk cacat yang dikembalikan yaitu dalam kemasan batangan $1 \mathrm{~kg}$ karena produk tersebut banyak mengalami kerusakan. Produk cacat tersebut sebesar 73 yang presentasenya adalah $0,86 \%$

\section{Biaya Kegagalan Eksternal}

Biaya kegagalan eksternal yang pengeluarannya 1,77\% dan biaya nya sebesar Rp. 14.500.000. Keluhan konsumen yang banyak apalagi pada bulan juli yaitu setelah lebaran karena pada saat itu UD. Mutiara Rasa Jember tidak memproduksi begitu banyak jadi banyak keluhan konsumen yang terjadi. Biaya garansi yang dikeluarkan selama tahun 2017 juga stabil karena tidak mengalami kenaikan.

\section{Dokumen yang Digunakan dalam Sistem Penggajian pada CV. Lisa Jaya Mandiri}

1. Dokumen Pendukung Perubahan Gaji dan Upah

Dokumen ini dikeluarkan oleh fungsi administrasi yang juga merangkap sebagai fungsi kepegawaian pada CV. Lisa Jaya Mandiri yang bertugas dalam memberikan surat-surat keputusan atas perubahan gaji dan upah kepada karyawan, baik dalam kenaikan pangkat atau berupa kenaikan gaji atau upah yang didasarkan pada surat keputusan direktur keuangan CV. Lisa Jaya Mandiri.

2. Kartu Jam Hadir

Dokumen ini digunakan oleh fungsi pencatat waktu untuk mencatat jam hadir setiap karyawan di perusahaan, fungsi pencatatan ini juga dilakukan oleh satu orang yaitu bagian administrasi. Dokumen tersebut berupa absensi karyawan yang dilakukan setiap jam kerja dan sesudah waktu pulang, yang dilakukan dengan cara tandatangan setiap karyawan yang hadir pada absensi yang sudah disediakan pada CV. Lisa Jaya Mandiri.

3. Daftar Gaji dan Daftar Upah

Dokumen ini dibuat oleh bagian administrasi CV. Lisa Jaya Mandiri yang berisi jumlah gaji dan upah bruto setiap karyawan, dikurangi dengan potongan-potongan berupa utang karyawan, iuran, dan lain sebagainya. Dimana sistem pemotongan gaji dan upah sudah dilaksanakan cukup baik sesuai otorisasi direktur keuangan CV. Lisa Jaya Mandiri.

4. Amplop Gaji dan Upah

Uang gaji yang telah direkap yang dicatat oleh bagian administrasi, selanjutnya akan dibayarkan kepada karyawan dengan menggunakan amplop gaji dan upah. Di halaman muka amplop gaji dan upah setiap karyawan sudah berisikan informasi mengenai nama karyawan, nomor identifikasi karyawan dan jumlah gaji bersih yang diterima karyawan CV. Lisa Jaya Mandiri.

5. Bukti Kas Keluar

Dokumen ini merupakan perintah pengeluaran yang dibuat oleh fungsi administrasi berdasarkan informasi dalam daftar gaji dan upah yang telah dibuat sebelumnya. Bukti kas keluar untuk pembayaran gaji dan upah karyawan ini sudah diotorisasi oleh direktur keuangan.

Catatan Akuntansi Yang Digunakan dalam Sistem Penggajian pada CV. Lisa Jaya Mandiri

1. Jurnal Umum

Dalam pencatatan gaji dan upah jurnal umum digunakan untuk mencatat gaji dan upah yang dilakukan pada bagian pembukuan pada CV. Lisa Jaya Mandiri. Pada CV. Lisa Jaya Mandiri peakaian jurnal umum telah sesuai dengan teori yaitu dimana semua pengeluaran dan pendapatan telah dicatat oleh perusahaan berdasarkan tanggal transaksi yang dilakukan.

2. Buku Besar

Buku besar merupakan kumpulan dari akun-akun yang telah dilakukan dan dicatat dalam jurnal umum untuk biaya gaji dan upah, dalam hal ini bagian pembukuan yang melakukan pencatatan terhadap buku besar pada CV. Lisa Jaya Mandiri. Buku besar pada CV. Lisa Jaya Mandiri telah dicatat dengan baik sesuai dengan teori dan telah di pilah dan diterapkan dengan baik. 
Fungsi - Fungsi yang Terkait atas Sistem Akuntansi Penggajian pada CV. Lisa Jaya Mandiri.

1. Fungsi Administrasi

Fungsi adminsitrasi pada CV. Lisa Jaya Mandiri yang dijalankan oleh fungsi administrasi yang sekaligus dilakukan oleh 1 orang dalam 1 fungsi,yaitu sebagai pencatat waktu, dan pembuat daftar gaji dan upah. Melalui sub bagian pembukuan ini, bertugas untuk mencatat adanya kewajiban yang timbul serta bertugas dalam pembayaran gaji karyawan CV. Lisa Jaya Mandiri. Jaringan Prosedur dalam Sistem Akuntansi Penggajian pada CV. Lisa Jaya Mandiri. Berdasarkan hasil wawancara serta observasi langsung pada objek penelitian, pada CV. Lisa Jaya Mandiri terdapat jaringan prosedur yang membentuk sistem akuntansi penggajian yaitu disajikan berdasarkan hasil wawancara sebagai berikut:

2. Prosedur Pencatatan Waktu.

Prosedur pencatatan waktu hadir ini dilakukan oleh bagian administrasi, seperti absensi yang dilakukan pada CV. Lisa Jaya Mandiri. Prosedur pencatatan waktu ini dilakukan oleh karyawan tidak tetap, sedangkan untuk karyawan tetap juga melakukan presesnsi tapi tidak mempengaruhi besarnya pemberian gaji dan upah. Akan tetapi berdasarkan kebijakan pimpinan perusahaan CV. Lisa Jaya Mandiri otorisasi atau persetujuan dilakukan secara bersama-sama.

3. Prosedur Pembuat Daftar Gaji dan Upah.

Dalam prosedur ini, pembuat daftar gaji dan upah membuat daftar gaji dan upah.Bagi karyawan tetap mengalami perubahan gaji dan upah apabila mengalami perubahan kenaikan tingkat jabatan, golongan, dan keluarganya bertambah.Sedangkan untuk karyawan tiadak tetap daftar upah disesuaikan dengan jumlah hari kerjanya.

4. Prosedur Pembuatan Bukti Kas Keluar.

Prosedur ini melibatkan fungsi pembukuan atau keuangan, setelah membuat daftar gaji dan upah selesai kemudian fungsi keuangan membuat bukti kas keluar untuk pembayaran gaji dan upah, setelahnya bukti kas keluar tersebut diserahkan pada bagian bendahara yang sekaligus fungsi administrasi melakukan pembayaran gaji dan upah pada karyawan CV. Lisa Jaya Mandiri.

5. Prosedur Pembayaran Gaji dan Upah.

Prosedur ini melibatkan fungsi administrasi dimana fungsi administrasi tersebut juga melakukan pembayaran yang merangkap jadi fungsi bendahara setelah kas keluar diotorisasi, fungsi administrasi/bendahara mengeluarkan bukti kas keluar.Untuk itu, gaji dapat di ambil di bagian bendahara atau kasir perusahaan.

Evaluasi Sistem Pengendalian Internal yang Berkaitan dengan Sistem Penggajian pada CV. Lisa Jaya Mandiri. Berdasarkan dari hasil penjabaran sekaligus analisis peneliti dan wawancara pada CV. Lisa Jaya Mandiri dan beserta bukti-bukti yang akan dilampirkan nantinya, selanjutnya peneliti dalam tahapan akhir ini akan memberikan evaluasi dan penilaian terhadap sistem pengendalian internal atas gaji dan upah pada CV. Lisa Jaya Mandiri, yaitu sebagai berikut:

\section{Aspek Organisasi.}

Struktur organisasi yang baik dalam perusahaan adalah struktur organisasi yang memisahkan tugas dan tanggungjawab dari setiap bagian organisasi. Pemisahan tugas yang jelas pada masing-masing bagian akan mempermudah pekerjaan, sehingga karyawan dapat bekerja sesuai dengan kedudukannya (Mulyadi ; 2008). Aspek oganisasi pada CV. Lisa Jaya Mandiri dimulai dari visi misi kemudian struktur organisasi dalam perusahaan tersebut, jika dilihat dari pemisahan tugas dan wewenang yang dilaksanakan oleh CV. Lisa Jaya Mandiri berdasarkan perbandingan dengan teori dan hasil observasi serta wawancara peneliti perlu diadakan evaluasi dan penambahan dokumen KPK. Pemisahan tanggungjawab dan wewenang pada CV. Lisa Jaya Mandiri pada bagian penggajian dan pengupahan dilakukan oleh satu orang yaitu bagian administrasi. Sehingga dengan tidak adanya pemisahan tugas dan wewenang tersebut, CV. Lisa Jaya Mandiri menuai beberapa kesalahan yaitu kesalahan pencatatan atau input data pada pemberian potongan gaji karyawan. Permasalahan yang terjadi pada CV. Lisa Jaya Mandiri ini dapat merugikan karyawan, misalkan kerugian yang berakibat pada karyawan yaitu yang kurang rinci dalam pemberian potongan pada karyawan. Sehingga mengakibatkan karyawan protes karena potongan gaji dirasa terlalu besar dari periode sebelumnya, sehingga gaji karyawan yang didapat tidak sesuai semestinya tanpa disadari oleh bagian administrasi tersebut. Faktor lain yang membuat adanya kesalahan tersebut tidak adanya kartu potongan gaji dan upah pada CV. Lisa Jaya Mandiri sehingga perlu ditambahkan dokumen terkait tersebut, demi efektifitasnya pemberian gaji dan upah karyawan pada CV. Lisa Jaya Mandiri. Untuk itu, perlu di adakan evaluasi kembali terhadap pengendalian internal atas gaji dan upah karyawan CV. Lisa Jaya mandiri Jember. 
2. Aspek Sistem Otorisasi.

Dari segi aspek otorisasi dari CV. Lisa Jaya Mandiri sudah memadai dan sesuai dengan unsur-unsur pengendalian internal menurut teori Mulyadi (2008), yaitu sudah ada kejelasan dalam sistem wewenang dan otorisasi, yaitu sebagai berikut : a) Setiap dokumen gaji dan upah yang lengkap akan diotorisasi langsung oleh pimpinan CV. Lisa Jaya Mandiri, b) Perintah lembur harus diotorisasi oleh kepala departemen karyawan yang bersangkutan, pada CV. Lisa Jaya Mandiri otorisasi ini dilaksanakan oleh pegawai bagian administrasi perusahaan.

3. Aspek Prosedur Pencatatan.

Dalam aspek prosedur pencatatan dalam CV. Lisa Jaya Mandiri berdasarkan analisa peneliti sudah memenuhi kriteria dari unsur-unsur sistem pengendalian internal menurut Mulyadi (2008), di dalam prosedur pencatatan perusahaan sudah melakukan prosedur secara lengkap mulai dari pembuatan daftar hadir sampai pada pembayaran gaji pada karyawan CV. Lisa Jaya Mandiri, serta ada kejelasan mengenai perubahan data pegawai dengan daftar gaji dan upah. Akan tetapi, kelemahan yang terjadi pada perusahaan terlihat pada pemisahan tugas dan wewenang karyawan yang masih diakukan oleh satu orang yang mengakibatkan kesalahan dalam pencatatan input data serta ketidaktepatan waktu pelaporan gaji dan upah pada CV. Lisa Jaya Mandiri Jember. Selain itu, dokumen dalam alur prosedur pencatatan pada CV. Lisa Jaya Mandiri hendaknya ditambahkan dengan Kartu Penghasilan Karyawan (KPK) untuk lebih meningkatkan keefektifan pelaporan serta meminimalisir kesalahan yang terjadi.

4. Aspek Praktik yang Sehat.

Dari segi aspek praktik yang sehat, pada CV. Lisa Jaya Mandiri ini masih belum sesuai dengan unsurunsur pengendalian internal yang tertera pada teori Mulyadi (2008) dan juga perlu adanya pembenahan kembali agar dapat meminimalisir permasalahan pada perusahaan dan dapat mempercepat input pemasukan data pada saat pembukuan yang dilakukan oleh bagian administrasi, yaitu sebagai berikut : a) Mengenai Mengenai kartu jam hadir, pada CV. Lisa Jaya Mandiri sudah memakai kartu jam hadir, akan tetapi kartu jam kerja tidak dapat dibandingkan sesuai dengan teori Mulyadi (2008), karena kartu jam hadir akan dibandingkan dengan kartu jam kerja yang akan dipakai sebagai dasar distribusi biaya tenaga kerja langsung, dan kartu jam hadir tersebut nantinya dijadikan satu dengan absensi karyawan yang berupa rekap kartu jam hadir karyawan, b) Mengenai pemisahan tugas dan wewenang yang dilakukan dan dilaksanakan pada perusahaan juga masih butuh peningkatan dan pembenahan kembali, terutama pada fungsi administrasi/pembukuan dalam hal pemasukan data karyawan dan pembuatan gaji dan upah karyawan, c) Mengenai dokumen terkait pada CV. Lisa Jaya Mandiri yaitu kartu penghasilan karyawan (KPK) yang berisi pemberian potongan dan juga gaji dan upah karyawan, d) Masih minimnya penggunaan sistem terkomputerisasi dan hanya beberapa, seperti absensi otomatis pun belum digunakan, sehingga masih menggunakan absensi manual.

\section{Simpulan dan saran}

Berdasarkan data-data dan waawancara yang dilakukan oleh peneliti, maka peneliti mengambil kesimpulan sebagai berikut:

(1) Biaya Penilaian, Biaya ini terdiri dari biaya program pelatihan kualitas dan biaya pemilihan dan evaluasi pemasok bahan baku. Pengeluaran biaya pencegahan ini hanya 1,52\% dari total penjualan selama satu tahun. Biaya pencegahan ini mendukung dalam pengendalian kualitas produk pada UD. Mutiara rasa Jember, (2) Biaya Penilaian, Biaya ini terdiri dari biaya pemeriksaan dan pengujian bahan baku, biaya pemeriksaan kemasan, dan biaya pengawasan kegiatan prduksi. Pengeluaaran biaya penilaian ini sebesar $2,97 \%$ dari total penjualan selama satu tahun. Biaya penilian ini stabil dalam pengeluarannya. Jadi biaya penilaian efektif serta mendukung dalam pengendalian kualitas produk pada UD. Mutiara rasa Jember, (3). Biaya Kegagalan Internal, Biaya ini terdiri dari biaya pemeriksaan ulang dan biaya pengerjaan ulang. UD. Mutiara Rasa Jember dalam pengeluaran biaya internal nya yaitu sebesar $2,56 \%$ dari total penjualan selama satu tahun dan juga stabil karena dalam produksinya tidak terlalu banyak masalah. Tetapi dilihat dari biaya pemeriksaan ulang yaitu sebesar 2,03\% dari kemasan yang terjual, dan biaya pengerjaan ulang yaitu sebesar $0,86 \%$ dari kemasan yang terjual. Jadi biaya kegagalan internal ini mendukung dalam pengendalian produk pada UD. Mutiara Rasa Jember, (4) Biaya Kegagalan Eksternal, Biaya ini terdiri dari biaya keluhan konsumen dan biaya garansi. Biaya kegagalan eksternal pengeluarannya yaitu sebesar $1,77 \%$ dari total penjualan. Walaupun biaya ini mengalami kenaikan dan biaya garansi di UD. Mutiara 
Rasa Jember dalam pengeluarannya stabil. Jadi biaya kegagalan eksternal ini mendukung dalam pengendalian kualitas produk pada UD. Mutiara Rasa Jember.

Dari kesimpulan diatas penulis memberikan saran kepada UD. Mutiara Rasa Jember untuk mengatasi permasalahan yang dihadapi: UD. Mutiara Rasa Jember sebaiknya lebih teliti dan lebih rinci dalam pencatatan biaya kualitas yang terjadi ditahun berikutnya agar perusahaan dapat melakukan pengukuran terhadap biaya kualitas yang akan terjadi. Dan sebaiknya biaya-biaya yang dikeluarkan oleh perusahaan dilaporkan dalam suatu laporan biaya kualitas.

\section{Daftar Rujukan}

Dunia, Firdaus Achmad dan Abdullah Wasilah. 2012. Akuntansi Biaya. Edisi 3, Jakarta : Salemba Empat.

Dewi, Sofia Prima dan Septian Bayu Kristanto. 2015. Akuntansi Biaya. Bogor : Inmedia.

Eliyana R. N. (2009). Pengaruh Biaya Kualitas Terhadap Produk Rusak Pada Cv. Aneka Ilmu Semarang. Jurnal Akuntansi Uness. Vol 2 No 1.

Hansen dan Mowen. 2004. Manajemen Biaya, Edisi Bahasa Indonesia. Buku Kedua. Jakarta : Salemba Empat.

Hansen dan Mowen . 2005. Management Accounting. Edisi 7. Jakarta : Salemba Empat.

. 2007. Akuntansi Manajemen. Edisi 7. Jakarta : Salemba Empat

Jessie Kristina. 2018. Peranan analisis biaya kualitas dalam pengendaliankualitas untuk mengurangi kagagalan produk pada PT. Bisma. Jurnal Akuntansi Universitas Katolik Parahyangan. Volume 2 no 2 .

Lilis Puji Rahayu. 2017. Analisis Pengaruh Biaya Kualitas Terhadap Produk Rusak Pada Ud. Batu Licin. Jurnal Simki-Economic. Vol. 01 No. 09.

Meirlina Tanjung. (2016). Analisis Biaya Kualitas Pada Pt Sinar Alam Permai Palembang. Jurnal Akuntansi Unila Volume 1 no 2.

Prihantoro, Rudy. 2012. Konsep Pengendalian Mutu. Bandung : Remaja Rosdakarya

Ratag,dkk. (2013). Penerapan Biaya Kualitas dalam Menigkatkan Efisiensi Biaya Produksi : Studi kasus pada PT. Tropica Cocoprima. Jurnal Riset Akuntansi Going Concern FEB UNSRAT. Universitas Sam Ratulangi Manado

Riki Martusa (2011). Peranan Analisis Biaya Kualitas Dalam Meningkatkan Efisiensi Biaya Produksi. Akurat Jurnal Ilmiah Akuntansi Universitas Kristen Maranatha. Vol. 2 No. 4.

Sugiyono. 2012. Metode Penelitian Kuantitatif, kualitatif, dan R\&D. Bandung : Alfabeta.

Yamit, Zulian. 2010. Manajemen Kualitas Produk \& Jasa. Edisi Pertama. Yogyakarta : Ekonisia. 